\title{
Effect of growth condition on in-vitro susceptibility of Shigella dysenteriae type 1 to killing by murine peritoneal macrophages
}

\author{
M. A. HAQUE, S. YOSHINO, K. OHKI, S. INADA and O. KOHASHI \\ Department of Microbiology, Saga Medical School, 5-1-1 Nabeshima, 849 Saga, Japan
}

\begin{abstract}
The intracellular fate of Shigella dysenteriae type 1 strains grown in casamino acid-yeast extract (CYE) broth and nutrient broth (NB) was studied in casein-elicited mouse peritoneal macrophages. Virulent strains 14731 and W30864 cultured in NB and opsonised with normal mouse serum were susceptible to killing by peritoneal macrophages (66 SEM $1.7 \%$ killing by $2 \mathrm{~h}$ ). In contrast, both strains grown in CYE broth and opsonised with normal mouse serum showed resistance to killing by peritoneal macrophages (76 SEM 1.4\% survival by $2 \mathrm{~h}$ ). Electronmicroscopy demonstrated that the bacteria escaped from the phagosome compartment by lysing the phagocytic vacuole and remained within the cytoplasm. Lipopolysaccharide (LPS) stimulated peritoneal macrophages to kill the opsonised strains 14731 and W30864 grown in CYE broth (85.4 SEM 1.6\% killing by $2 \mathrm{~h}$ ). Recombinant murine gamma interferon (rIFN- $\gamma$ ) also stimulated macrophages to kill CYE-grown bacteria (52.1 SEM 1.3\% killing by 2 h). However, an avirulent rough mutant strain W30864-22 grown in either NB or CYE broth showed marked susceptibility to killing by peritoneal macrophages, which was similar to that of NB-grown strain 14731 or W30864. The results of the present study suggest that in-vitro growth conditions may modulate the susceptibility of $S$. dysenteriae type 1 to killing by phagocytes.
\end{abstract}

\section{Introduction}

Shigella dysenteriae type 1 causes bloody, purulent diarrhoea by invading and destroying colonic epithelial cells and inducing an inflammatory response in the mucosal tissues [1]. The organism enters epithelial cells by induced phagocytosis and rapidly lyses the phagocytic vacuole leading to its release into the cytoplasm [2,3]. Strains of $S$. dysenteriae type 1 produce high levels of a potent cytotoxin called Shiga toxin. Recent studies have suggested that Shiga toxin may exacerbate the disease by specifically damaging capillaries in the colonic mucosa and by mediating the influx of inflammatory cells into the intestinal compartment [4]. It is well known that intracellular multiplication of the invading pathogen is a prerequisite for virulence. The correlation between the rate of intracellular multiplication and the level of Shiga toxin production has been proposed as one of the means by which invasive shigellae preferentially incorporate amino acids through the shut off of host cell protein synthesis [5]. Studies have demonstrated that invasive strains of $S$. dysenteriae type 1 induce early cell damage even in the toxin-resistant cell line Henle-407 $[5,6]$. It has been shown recently that $S$. dysenteriae

Received 5 May 1995; accepted 5 June 1995.

*Corresponding author: O. Kohashi. type 1 produces an extracellular slime layer under certain growth conditions that mediates resistance to killing by serum and neutrophils $[7,8]$. Many studies of phagocyte interactions with facultative intracellular bacteria have investigated the mechanisms by which these pathogens frustrate the host's microbicidal capabilities and how phagocytes bind and phagocytose these pathogens.

Strains of $S$. dysenteriae type 1 are generally nonfimbriated [9-11] and, unless opsonised, are unable to bind to phagocytic cells or to induce an oxidative burst in these cells. Lipopolysaccharide (LPS) activates macrophages to produce and release several cytokines $[12,13]$. The mechanisms involved in the interaction of LPS with surface receptors, thereby activating secondary signals and ultimately activating the macrophage, are currently being investigated by many groups [14-16]. Interferon-gamma (IFN- $\gamma$ ) also stimulates macrophages [17], although its efficacy has not been tested against $S$. dysenteriae type 1 .

The aim of this study was to understand the pathogenesis of $S$. dysenteriae type 1 infection by investigating its interactions with murine peritoneal macrophages. Specific objectives of the study were: to test the ability of casein-elicited peritoneal macrophages to engulf and kill strains of $S$. dysenteriae type 
1 in the presence of normal serum; to compare the effect of bacterial culture conditions on the sensitivity to killing by peritoneal macrophages; and to evaluate the enhanced phagocytic activities of peritoneal macrophages stimulated by rIFN- $\gamma$ and LPS.

\section{Materials and methods}

\section{Bacterial strains}

$S$. dysenteriae type 1 strain W30864 and its O-antigennegative derivative W30864-22 [18,19] were obtained from the National Institute of Health (NIH), Japan. Strain 14731 [11] was obtained from the International Centre for Diarrhoeal Disease Research, Bangladesh (ICDDR, B), Dhaka. Strains W30864 and 14731 were virulent as judged by Congo red binding [20] and positive Sereny test results [21].

\section{Media and growth conditions}

Bacteria were grown in Casamino acid-Yeast extract Broth [11], pH 7.4 (Difco Laboratories) supplemented with $1 \mathrm{mM} \mathrm{CaCl}{ }_{2}$ (CYE) in screw-capped test tubes containing $5 \mathrm{ml}$ of medium, for $18 \mathrm{~h}$ with shaking $(100 \mathrm{rpm})$ at $37^{\circ} \mathrm{C}$. Bacteria were also grown in Nutrient Broth (NB) (Eiken Chemical Co., Tokyo, Japan), for $18 \mathrm{~h}$ with shaking $(100 \mathrm{rpm})$ at $37^{\circ} \mathrm{C}$.

\section{Sera}

Normal sera from $20 \mathrm{BALB} / \mathrm{c}$ mice were pooled and stored in $1-\mathrm{ml}$ portions at $-70^{\circ} \mathrm{C}$. To opsonise bacteria with fresh sera, a portion was thawed immediately before being used in the experiment.

\section{Macrophages}

Macrophages were elicited from $\mathrm{BALB} / \mathrm{c}$ mice by intraperitoneal injection of sodium caseinate (Wako Pure Chemicals Industries Ltd, Osaka, Japan) $5 \%$ in $\mathrm{NaCl} 0.9 \%, 4$ days before harvesting as described previously [22]. Briefly, peritoneal cells were collected by peritoneal lavage with $3 \mathrm{ml}$ of PBS. Cells were then washed in $\mathrm{Ca}^{2+}, \mathrm{Mg}^{2+}$-free Hanks's Balanced Salts Solution (HBSS) and resuspended in RPMI 1640 medium (Flow Laboratories Inc., McLean, VA, USA) plus fetal calf serum (Gibco Laboratories, Grand Island, NY, USA) $10 \%$. After washing, macrophages were incubated at $37^{\circ} \mathrm{C}$ in $\mathrm{CO}_{2} 5 \%$ in $35-\mathrm{mm}$ plastic tissue culture dishes and allowed to adhere for $4 \mathrm{~h}$, after which time the non-adherent cells were removed by washing with HBSS.

\section{Opsonisation}

To opsonise the strains of $S$. dysenteriae type 1 , bacterial suspensions $\left(2 \times 10^{6} \mathrm{cfu} / \mathrm{ml}\right)$ were incubated with normal mouse serum $10 \% \mathrm{v} / \mathrm{v}$ at $37^{\circ} \mathrm{C}$ for $30 \mathrm{~min}$. Strains were also incubated at $37^{\circ} \mathrm{C}$ for $30 \mathrm{~min}$ with complement-inactivated mouse serum. Bacterial suspensions were then washed twice with PBS and suspended in serum-free RPMI.

\section{In-vitro assay for survival of bacteria within macrophages}

Macrophages were incubated in individual wells of 24well plates (Coster, Cambridge, MA, USA) at a concentration of $2 \times 10^{5}$ cells/well in a total volume of $1 \mathrm{ml}$ of RPMI 1640 supplemented with complementinactivated fetal calf serum (Gibco Laboratories) and allowed to adhere for $3 \mathrm{~h}$ at $37^{\circ} \mathrm{C}$. After incubation, non-adherent cells were washed off and the medium was replaced by $1 \mathrm{ml}$ of pre-opsonised bacterial suspension $\left(2 \times 10^{6} \mathrm{cfu} / \mathrm{ml}\right)$ in RPMI without serum. Plates were centrifuged for $10 \mathrm{~min}$ at $2200 \mathrm{~g}$ and incubated at $37^{\circ} \mathrm{C}$ for $15 \mathrm{~min}$ to allow entry of bacteria into the cells. Plates were washed twice with HBSS and covered with $1 \mathrm{ml}$ of RPMI supplemented with $2 \mathrm{mM}$ glutamine and gentamicin $(25 \mu \mathrm{g} / \mathrm{ml})$. This step was considered as time zero. Plates were then sampled at 0 , $30,60,120$ and $180 \mathrm{~min}$. After infection, triplicate macrophage samples from each well were lysed with Triton X-100 (0.1\%), plated and the number of shigellae was counted.

Peritoneal macrophages were also plated in triplicate in 24-well tissue culture plates at $2 \times 10^{5}$ cells/well and were incubated overnight at $37^{\circ} \mathrm{C}$ with either rIFN- $\gamma 100 \mathrm{U}$ or LPS $10 \mu \mathrm{g} / \mathrm{ml}$. After treatment, plates were washed with HBSS and bacterial suspensions were added, and the assays performed as described above.

\section{Scanning electronmicroscopy}

At selected intervals after infection (between time zero and $15 \mathrm{~min}$ of incubation), cells were fixed for $1 \mathrm{~h}$ at room temperature with glutaraldehyde $2.5 \%$ in $0.1 \mathrm{M}$ cacodylate buffer ( $\mathrm{pH}$ 7.2) (Wako Pure Chemicals). They were washed with the same buffer and the cells were fixed for $1 \mathrm{~h}$ at room temperature with osmium tetroxide $1 \%$ in $0.1 \mathrm{M}$ cacodylate buffer. The fixed samples were dehydrated with ethanol and critical point-dried. The samples were then coated with goldpalladium and analysed by scanning electron microscopy (Hitachi, S-700).

\section{Transmission electronmicroscopy}

To identify more precisely the intracellular behaviour of $S$. dysenteriae type 1, transmission electronmicroscopy of strain 14731-infected macrophages was performed as described previously [3]. Briefly, infected macrophages were fixed at selected intervals for $1 \mathrm{~h}$ at room temperature with glutaraldehyde $2.5 \%$ in $0.1 \mathrm{M}$ cacodylate buffer. They were then washed and incubated overnight at $4^{\circ} \mathrm{C}$ in this buffer. Further fixation was performed in osmium tetroxide $1 \%$ in the same 
buffer. The cells were then scraped off the culture dishes with a "rubber policeman" diagonal (Wakenyaku Co., Ltd, Japan), concentrated in agar, and treated for $1 \mathrm{~h}$ with uranyl acetate $1 \%$. Samples were then dehydrated and embedded in Epon ${ }^{\circledR}$. Thin sections were stained with uranyl acetate $2 \%$ and lead citrate.

\section{Results}

\section{Effects of serum opsonins on binding and} phagocytosis of $S$. dysenteriae type 1

Strains of $S$. dysenteriae type 1 grown in either NB or CYE broth and opsonised with normal mouse serum were bound and taken up equally by mouse peritoneal macrophages. Opsonisation of both virulent and avirulent strains with complement-inactivated serum reduced the binding and uptake of bacteria compared with opsonisation with normal serum (Table 1). Opsonisation of a rough mutant strain W30864-22 with either normal serum or complement-inactivated serum showed an increased uptake of bacteria compared with that of virulent strains. However, bacterial culture condition did not affect the uptake of either virulent or avirulent strains of $S$. dysenteriae type 1 (Table 1). Under non-opsonic conditions, there was no binding or uptake of bacteria by peritoneal macrophages (data not shown).

\section{Survival of $S$. dysenteriae type 1 within peritoneal macrophages}

Strains 14731 and W30864 grown in CYE broth and opsonised with normal mouse serum survived within the peritoneal macrophages (76 SEM $1.4 \%$ bacterial survival) (Fig. 1). In contrast, an avirulent rough mutant strain W30864-22 grown in CYE broth showed increased susceptibility to killing by peritoneal macrophages (Fig. 1). The numbers of the rough mutant had decreased by $63 \%$ at $60 \mathrm{~min}$ and $85 \%$ after incubation for $120 \mathrm{~min}$.

Intracellular killing of strains 14731, W30864 and W30864-22 by peritoneal macrophages

Opsonised strains 14731 and W30864 grown in NB

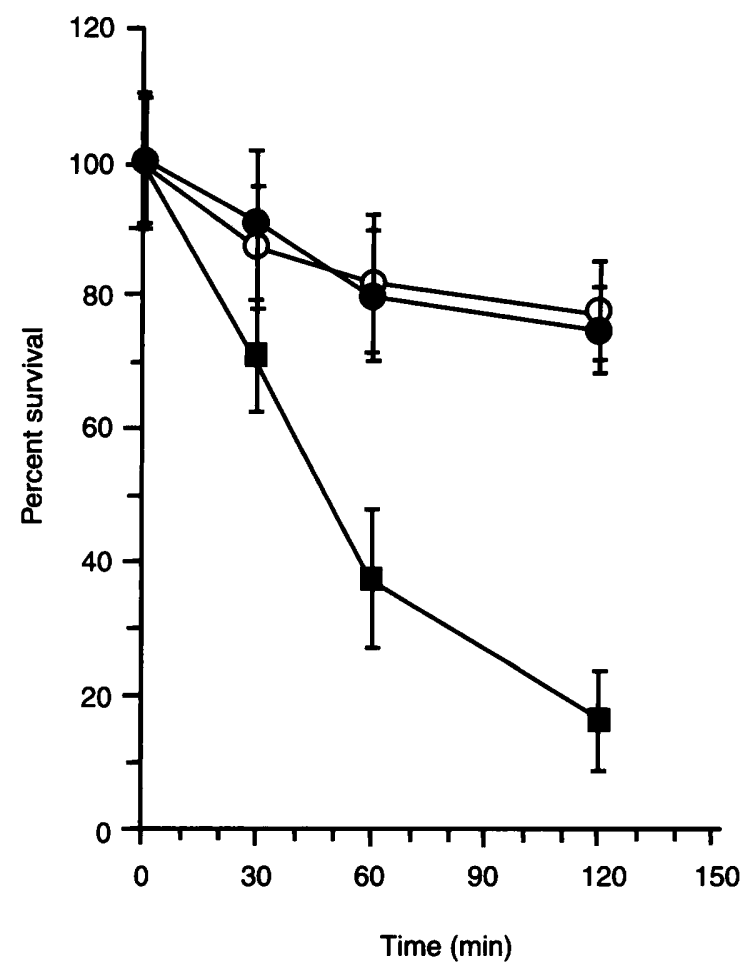

Fig. 1. Intracellular survival of $S$. dysenteriae type 1 in murine peritoneal macrophages. Each value is the mean and SEM for three different determinations at each time point; -O- , 14731; - - , W30864; - - - , W3086422.

were killed (66 SEM 1.7\%) by peritoneal macrophages within 120 min of incubation (Fig. 2). The intracellular killing of strain W30864-22 was enhanced relative to that of strain 14731 or W30864, and the kinetics of killing of both virulent and avirulent strains was almost the same after incubation for 30 and $60 \mathrm{~min}$.

\section{Effect of rIFN- $\gamma$ and LPS on macrophage killing activity}

Macrophages exhibited significantly enhanced ability to kill (52.1 SEM $1.3 \%$ killing by $2 \mathrm{~h}$ ) $S$. dysenteriae type 1 when they were activated with rIFN- $\gamma$ (Fig. 3A). The intracellular killing of $S$. dysenteriae type 1 by LPS-activated macrophages was increased (85.4 SEM $1.6 \%$ killing by $2 \mathrm{~h}$ ) (Fig. 3B) compared to that by the rIFN- $\gamma$ activation.

Table 1. Binding and uptake of $S$. dysenteriae type 1 by murine peritoneal macrophages

\begin{tabular}{|c|c|c|c|c|}
\hline \multirow[b]{3}{*}{ Strain no. } & \multicolumn{4}{|c|}{ Uptake of bacteria after incubation for $15 \mathrm{~min} *$} \\
\hline & \multicolumn{2}{|c|}{ CYE broth-grown bacteria in } & \multicolumn{2}{|c|}{ NB-grown bacteria in } \\
\hline & $\begin{array}{l}\text { normal } \\
\text { serum }\end{array}$ & $\begin{array}{l}\text { complement-inactivated } \\
\text { serum }\end{array}$ & $\begin{array}{l}\text { normal } \\
\text { serum }\end{array}$ & $\begin{array}{c}\text { complement-inactivated } \\
\text { serum }\end{array}$ \\
\hline 14731 & 90.25 & 48.75 & 87.00 & 51.75 \\
\hline W30864 & 94.75 & 50.25 & 90.00 & 47.00 \\
\hline W30864-22 & 152.00 & 72.50 & 151.00 & 69.50 \\
\hline
\end{tabular}

${ }^{*}$ Bacteria were opsonised with mouse serum $10 \%$ as indicated and then mixed 10:1 with casein-elicited peritoneal macrophages for 15 min at $37^{\circ} \mathrm{C}$. At time zero, macrophages were lysed and samples were plated and counted. Results from three experiments are presented as the mean baterial counts $\left(10^{4}\right)$; SEM were $<10 \%$ 


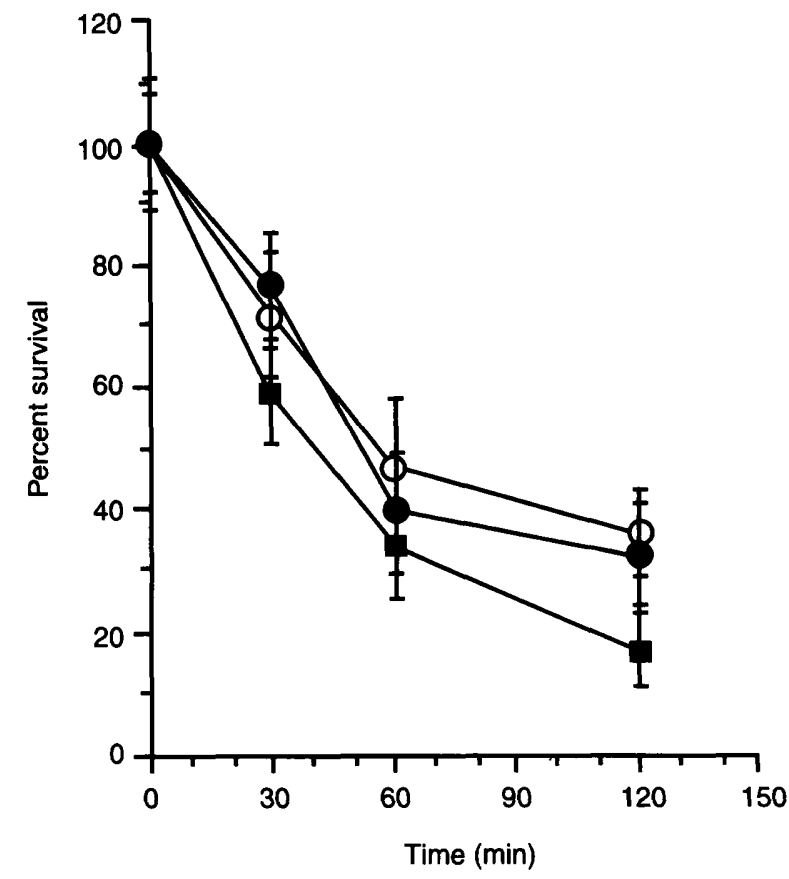

Fig. 2. Intracellular killing of $S$. dysenteriae type 1 in murine peritoneal macrophages. Each value is the mean and SEM for three different determinations at each time point; -O- , 14731; -O- , W30864; - - - , W3086422.

\section{Electronmicroscopy of strain 14731-infected peritoneal macrophages}

Scanning electronmicroscopy of CYE broth-grown strain 14731-infected macrophages showed the binding

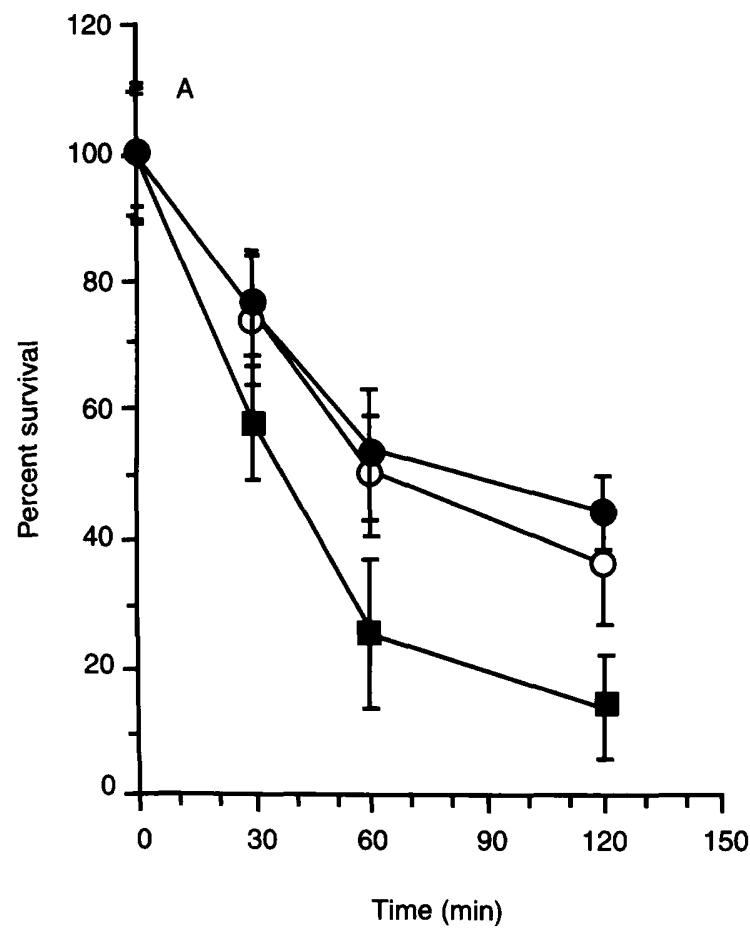

of bacteria to mouse peritoneal macrophages at $5 \mathrm{~min}$ (Fig. 4A). Strain 14731 grown in CYE medium was also used in the transmission electronmicroscopy study for a better understanding of intracellular survival of $S$. dysenteriae type 1 . These electronmicroscopic observations demonstrated that some bacteria were located inside the phagosomes (Fig. 4B.1), and some bacteria exhibited lysis of the membrane-bound vacuole (Fig. 4B.2) after $30 \mathrm{~min}$. Electronmicroscopy of strain 17431-infected macrophages also demonstrated some bacteria in the cytoplasm (Fig. 4C.3), and the remaining bacteria were degraded (Fig. 4C.4) after incubation for $120 \mathrm{~min}$.

\section{Discussion}

S. dysenteriae type 1 strains 14731 and W30864 grown in NB were killed effectively by casein-elicited peritoneal macrophages, whereas the same strains grown in CYE broth were resistant even in the presence of normal serum. It has been demonstrated previously that $S$. dysenteriae type 1 produces an extracellular slime layer when grown in CYE broth, but not in $\mathrm{NB}$, and that the bacteria become resistant to killing by human polymorphonuclear leucocytes $[7,8]$. Taken together, these results indicate that the culture conditions affect the susceptibility of $S$. dysenteriae strains to killing by phagocytes. Electronmicroscopy demonstrated that a small number of bacteria escape from the phagosome compartment (Fig. 4B.2 and Fig. 4C.3). After evasion, bacteria start to multiply

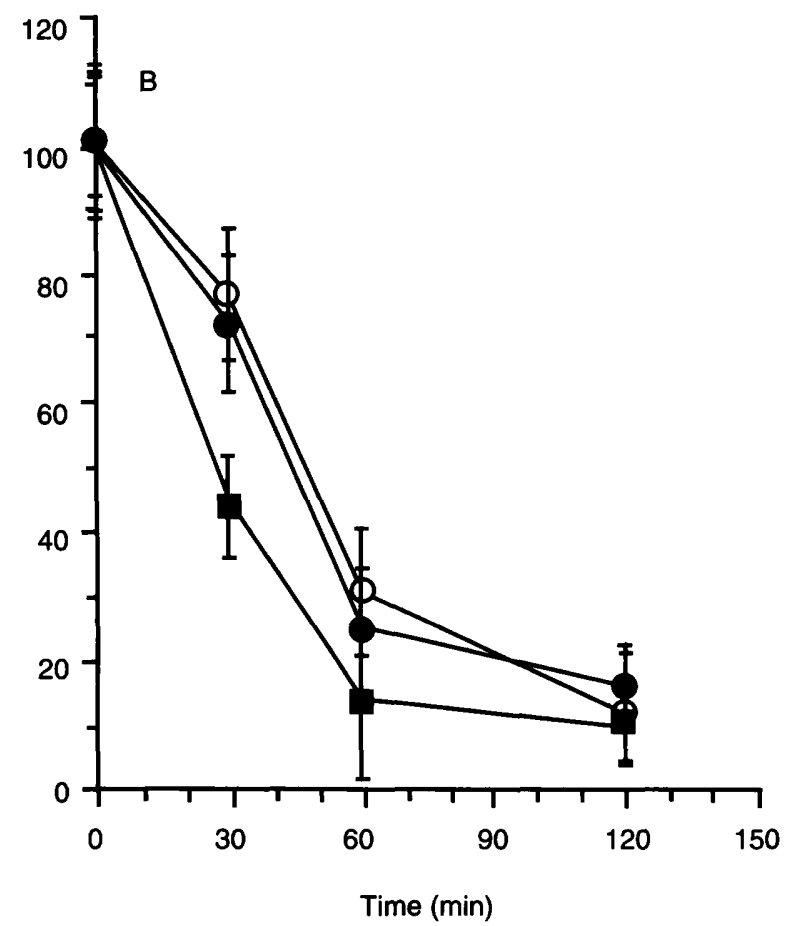

Fig. 3. Effect of A, murine recombinant IFN- $\gamma$ and $\mathbf{B}$, lipopolysaccharide on macrophage killing activity. Peritoneal macrophages were incubated with either rIFN- $\gamma 100 \mathrm{U} / \mathrm{ml}$ or LPS $10 \mu \mathrm{g} / \mathrm{ml}$ for $24 \mathrm{~h}$. Macrophages were then infected with CYE broth-grown 14731 (-O-), W30864 (-O-) and W30864-22 (-口-). The results are expressed as mean and SEM of three experiments. 


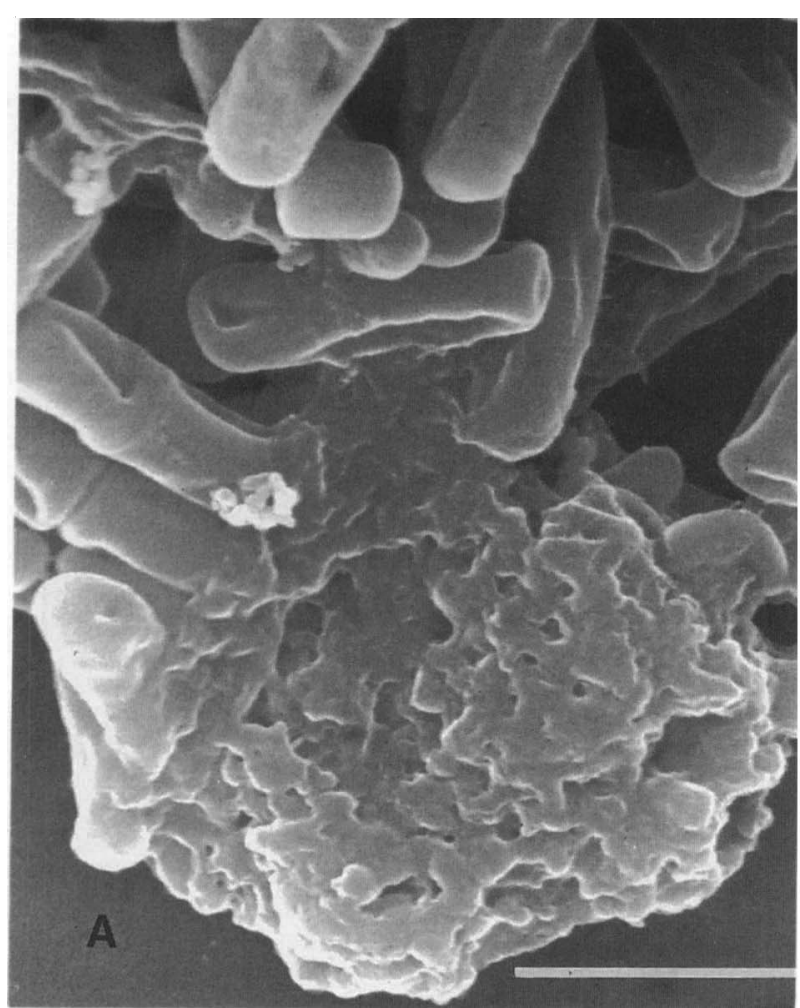

Fig. 4. Electronmicrographs showing the phagocytosis of $S$. dysenteriae type 1 strain 14731 by mouse peritoneal macrophages. Bacteria grown in CYE broth were opsonised with normal mouse serum, and were incubated with peritoneal macrophages. A, Scanning electronmicrograph demonstrating the binding of 14731 to the macrophage at $5 \mathrm{~min}$. B and $\mathbf{C}$, Transmission electronmicrographs showing the various stages of phagocytosis and evasion - bacteria within the phagosome (1), and evasion of bacteria by lysing the phagosome membrane after incubation for $30 \mathrm{~min}$ (2); bacteria within the cytoplasm (3), and degranulation of 14731 (4) after incubation for $120 \mathrm{~min}$.

intracellularly, and this was confirmed by colony counting after incubation for $120 \mathrm{~min}$. Because the rough mutant strain W30864-22 showed an increased susceptibility to peritoneal macrophages, the possible role of the $\mathrm{O}$-antigenic side chain in the evasion process cannot be excluded. It seems that the strains of $S$. dysenteriae type 1 produced longer $\mathrm{O}$-antigenic side chains when grown in CYE broth, and became more virulent. In this capacity, the $S$. dysenteriae type 1 virulence plasmid may also encode a product that renders bacteria resistant to killing by macrophages under certain growth conditions.

Macrophages stimulated by IFN- $\gamma$ killed strains 14731
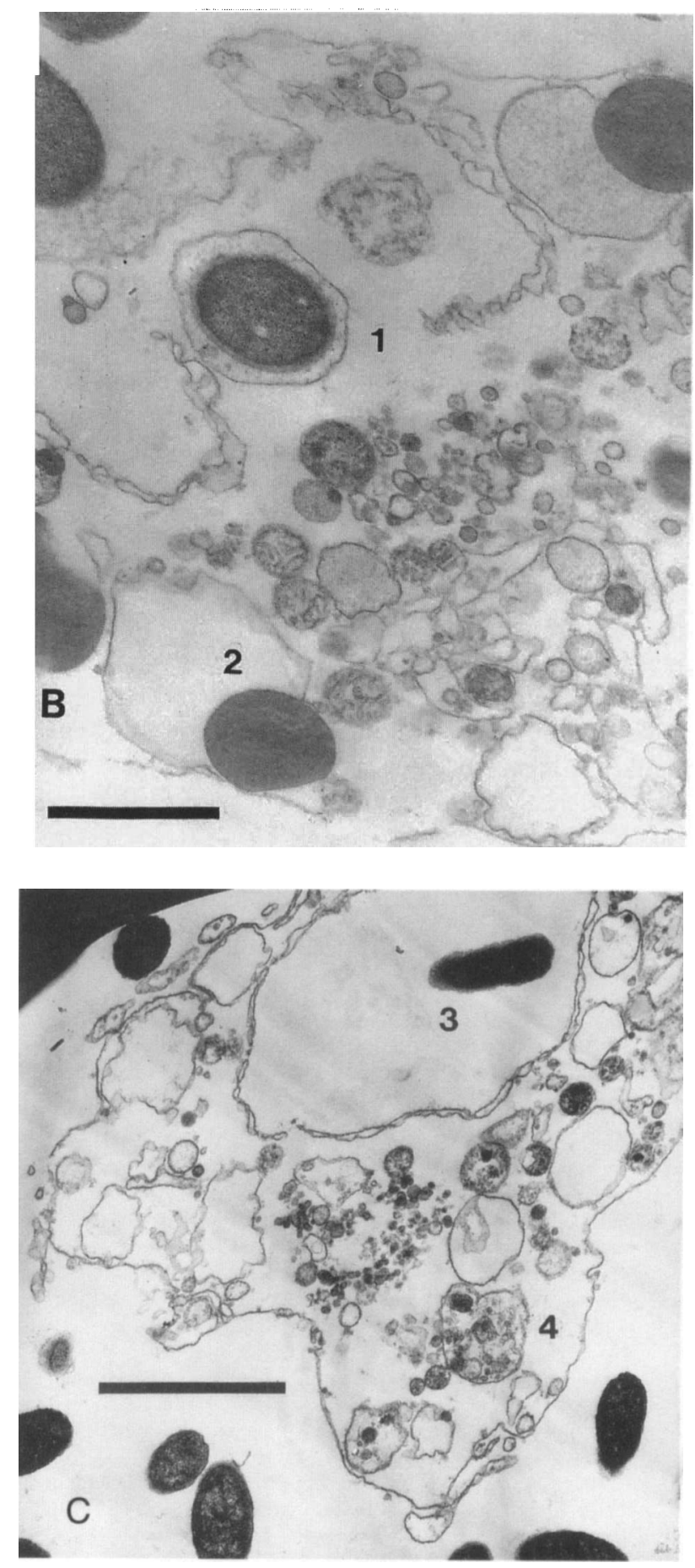

and W30864 grown in CYE broth effectively. The reduction in the percentage of viable bacteria was more in the LPS-activated macrophages than those observed in rIFN- $\gamma$-activated macrophages, possibly by the increased release of toxic oxygen intermediates, hydrogen peroxide and nitric oxide [23-26].

Transmission electronmicroscopy of macrophages infected with strain 14731 demonstrated that evasion of killing in $S$. dysenteriae strains was the result of early and efficient lysis of the phagosome membrane. The Shigella virulence plasmid may play a role in this process. After lysing the phagocytic vacuole, bacteria remained within the cytoplasm as observed by 
transmission electronmicroscopy after incubation for $120 \mathrm{~min}$. Intracellular multiplication, ability to lyse phagocytic vacuoles, and contact haemolysis have been shown to be virulence factors for $S$. flexneri [3]. Haemolytic activity has also been demonstrated in strains of $S$. dysenteriae type 1 [27], and the bacteria also creates tissue damage through their highly efficient invasiveness and intracellular multiplication. Secretion of Shiga toxin would certainly represent an additional advantage by precipitating cell death [5]. Studies on the role of Shiga toxin in pathogenesis have focused primarily on its potent cytotoxic activity, and its role in colonic ulceration [28-30]. Shiga toxin also induces expression of pro-inflammatory cytokines from murine peritoneal macrophages [31].

These electronmicroscopic studies suggest that $S$. dysenteriae type 1 may be a facultative intracellular micro-organism which escapes from the phagosome (Fig. 4B.2 and 4C.3), and multiplies intracellularly. However, during natural infection, macrophages may produce a higher bactericidal activity and phagocytose $S$. dysenteriae more efficiently than peritoneal macrophages in vitro.

We thank Drs F. Qadri and H. Watanabe for providing bacterial strains. We also thank T. Tabata for technical assistance and I. Nanbu for secretarial assistance.

This work was supported by a Grant-in-Aid for Scientific Research from the Ministry of Education, Science and Culture of Japan.

\section{References}

1. Labrec EH, Schneider H, Magnani TJ, Formal SB. Epithelial cell penetration as an essential step in the pathogenesis of bacillary dysentery. $J$ Bacteriol $1964 ; 88$ : 1503-1518.

2. Makino S, Sasakawa C, Kamata K, Kurata T, Yoshikawa M. A genetic determinant required for continuous reinfection of adjacent cells on large plasmid in S. flexneri 2a. Cell 1986; 46: 551-555.

3. Sansonetti PJ, Ryter A, Clerc P, Maurelli AT, Mounier J. Multiplication of Shigella flexneri within HeLa cells: lysis of the phagocytic vacuole and plasmid-mediated contact hemolysis. Infect Immun 1986; 51: 461-69.

4. Fontaine A, Arondel J, Sansonetti PJ. Role of Shiga toxin in the pathogenesis of bacillary dysentery, studied by using a Tox- mutant of Shigella dysenteriae 1. Infect Immun 1988; 56: 3099-3109.

5. Hale TL, Formal SB. Protein synthesis in HeLa or Henle 407 cells infected with Shigella dysenteriae 1, Shigella flexneri $2 \mathrm{a}$, or Salmonella typhimurium W118. Infect Immun 1981; 32: 137-144.

6. Clerc PL, Ryter A, Mounier J, Sansonetti PJ. Plasmid-mediated early killing of eucaryotic cells by Shigella flexneri as studied by infection of $\mathrm{J} 774$ macrophages. Infect Immun 1987; 55: 521-527.

7. Qadri F, Haque MA, Hossain A, Azim T, Alam K, Albert MJ. Role of Shigella dysenteriae type 1 slime polysaccharide in resistance to serum killing and phagocytosis. Microb Pathog 1993; 14: 441-449.

8. Qadri F, Haque MA, Hossain A, Albert MJ. Production of slime polysaccharides by Shigella dysenteriae type 1. Microbiol Immunol 1994; 38: 11-18.

9. Gbarah A, Mirelman D, Sansonetti PJ, Verdon R, Bernhard W, Sharon N. Shigella flexneri transformants expressing type 1 (mannose-specific) fimbriae bind to, activate, and are killed by phagocytic cells. Infect Immun 1993; 61: 1687-1693.
10. Mirelman D, Nuchamowitz Y, Izhar M. Interactions between intestinal cells and Shigellae. In: Agabian N, Eisen $\mathrm{H}$ (eds) Molecular biology of host-parasite interactions. New York, Alan R. Liss Inc. 1984: 321-330.

11. Qadri F, Haq S, Čžár I. Hemagglutinating properties of Shigella dysenteriae type 1 and other Shigella species. Infect Immun 1989; 57: 2909-2911.

12. Arata S, Newton C, Klein TW, Friedman H. Legionella pneumophila growth restriction in permissive macrophages cocultured with nonpermissive lipopolysaccharide-activated macrophages. Infect Immun 1993; 61: 5056-5061.

13. Gessani S, Testa U, Varano B et al. Enhanced production of LPS-induced cytokines during differentiation of human monocytes to macrophages. Role of LPS receptors. J Immunol 1993; 151: $3758-3766$.

14. Alcina A, Fresno M. Activation by synergism between endotoxin and lymphokines of the mouse macrophage cell line $\mathrm{J} 774$ against infection by Trypanosoma cruzi. Parasite Immunol 1987; 9: 175-186.

15. Wright SD, Levin SM, Jong MTC, Chad Z, Kabbash LG. CR3 (CD11b/CD18) expresses one binding site for Arg-Gly-Aspcontaining peptides and a second site for bacterial lipopolysaccharide. J Exp Med 1989; 169: 175-183.

16. Wright SD, Ramos RA, Tobias PS, Ulevitch RJ, Mathison JC. CD14, a receptor for complexes of lipopolysaccharide (LPS) and LPS binding protein. Science 1990; 249: 1431-1433.

17. Nathan C. Interferon-gamma and macrophage activation in cell-mediated immunity. In: Steinman RM, North RJ (eds) Mechanisms of host resistance to infectious agents, tumors, and allografts. New York, Rockefeller University Press. 1986: $165-184$.

18. Watanabe H, Nakamura A, Timmis KN. Small virulence plasmid of Shigella dysenteriae 1 strain W30864 encodes a 41,000 -dalton protein involved in formation of specific lipopolysaccharide side chains of serotype 1 isolates. Infect Immun 1984; 46: 55-63.

19. Watanabe H, Timmis KN. A small plasmid in Shigella dysenteriae 1 specifies one or more functions essential for $\mathrm{O}$ antigen production and bacterial virulence. Infect Immun 1984; 43: $391-396$

20. Qadri F, Hossain SA, Čižár I et al. Congo red binding and salt aggregation as indicators of virulence in Shigella species. $J$ Clin Microbiol 1988; 26: 1343-1348.

21. Serény B. Experimental Shigella keratoconjunctivitis. A preliminary report. Acta Microbiol Acad Sci Hung 1955; 2: 293-296.

22. Franzon VL, Arondel J, Sansonetti PJ. Contribution of superoxide dismutase and catalase activities to Shigella flexneri pathogenesis. Infect Immun 1990; 58: 529-535.

23. Klebanoff SJ. Oxygen metabolism and the toxic properties of phagocytes. Ann Intern Med 1980; 93: 480-489.

24. Murray HW, Cartelli DM. Killing of intracellular Leishmania donovani by human mononuclear phagocytes: evidence for oxygen-dependent and -independent leishmanicidal activity. $J$ Clin Invest 1983; 72: 32-44.

25. Wilson CB, Tsai V, Remington JS. Failure to trigger the oxidative metabolic burst by normal macrophages: possible mechanism for survival of intracellular pathogens. $J$ Exp Med 1980; 151: 328-46.

26. Nathan CF. Mechanisms of macrophage antimicrobial activity Trans R Soc Trop Med Hyg 1983; 77: 620-630.

27. Haider K, Albert MJ, Hossain A, Nahar S. Contact-haemolysin production by entero-invasive Escherichia coli and shigellae. J Med Microbiol 1991; 35: 330-337.

28. Louise CB, Obrig TG. Shiga toxin-associated hemolytic-uremic syndrome: combined cytotoxic effects of Shiga toxin, interleukin-1 $\beta$, and tumor necrosis factor alpha on human vascular endothelial cells in vitro. Infect Immun 1991; 59: 4173-4179.

29. Louise CB, Obrig TG. Shiga toxin-associated hemolytic uremic syndrome: combined cytotoxic effects of Shiga toxin and lipopolysaccharide (endotoxin) on human vascular endothelial cells in vitro. Infect Immun 1992; 60: 1536-1543.

30. O'Brien AD, Tesh VL, Donohue-Rolfe A et al. Shiga toxin biochemistry, genetics, mode of action, and role in pathogenesis. Curr Top Microbiol Immunol 1992; 180: 65-94.

31. Tesh VL, Ramegowda B, Samuel JE. Purified shiga-like toxins induce expression of proinflammatory cytokines from murine peritoneal macrophages. Infect Immun 1994; 62: 5085-5094. 